Section Editor

Mitchell S.V. Elkind, MD, MS

\title{
Teaching NeuroImages: TIA from an air embolism
}

Figure Noncontrast head CT

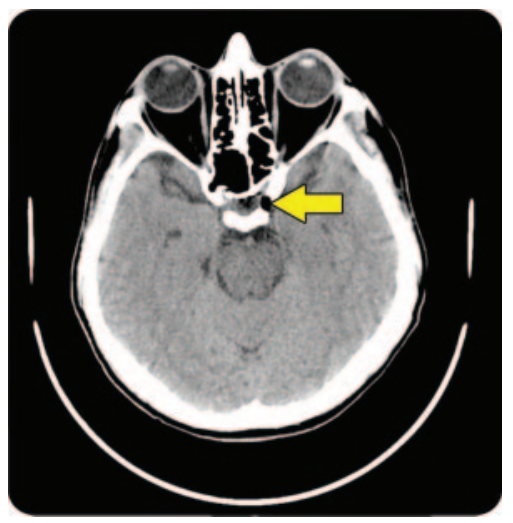

Noncontrast head CT demonstrates an air embolism (arrow) in the left cavernous sinus, suggestive of a paradoxical venous air embolism from injection of the portacath. This resulted in transient right-sided weakness prior to reaching the cavernous sinus.

A 39-year-old man undergoing chemotherapy for lymphoma presented emergently with right-sided weakness lasting 1 hour. The onset was seconds after his portacath was injected. A head CT was obtained (figure) and diffusion-weighted imaging MRI was negative. Echocardiogram confirmed a transatrial shunt. He was treated with $100 \%$ oxygen and provided with portacath teaching. Iatrogenic air emboli occur when thoracic pressure is less than atmospheric pressure. Venous emboli may become paradoxical via transcardiac shunts, resulting in relative brain ischemia. ${ }^{1}$ Administering $100 \%$ oxygen reduces bubble size by diffusion. Failing this, hyperbaric oxygen may help by increasing the solubility through raised pressure. ${ }^{2}$

\section{AUTHOR CONTRIBUTIONS}

Dr. Westwood: concept and design, acquisition of data, analysis and interpretation of data, drafting of the manuscript. Dr. Nguyen: concept and design, acquisition of data, analysis and interpretation of data, critical revision of the manuscript for important intellectual content, supervision.

\section{REFERENCES}

1. van Hulst RA, Klein J, Lachmann B. Gas embolism: pathophysiology and treatment. Clin Physiol Funct Imaging 2003;23:237-246.

2. Scruggs JE, Joffe A, Wood KE. Paradoxical air embolism successfully treated with hyperbaric oxygen. J Intens Care Med 2008;23:204-209. 


\title{
Neurology
}

\author{
Teaching NeuroImages: TIA from an air embolism \\ Andrew J. Westwood and Thanh N. Nguyen \\ Neurology 2011;77;e123 \\ DOI 10.1212/WNL.0b013e318238ee67
}

This information is current as of November 21, 2011

\section{Updated Information \& Services}

References

Subspecialty Collections

Permissions \& Licensing

Reprints including high resolution figures, can be found at: http://n.neurology.org/content/77/21/e123.full

This article cites 2 articles, 0 of which you can access for free at: http://n.neurology.org/content/77/21/e123.full\#ref-list-1

This article, along with others on similar topics, appears in the following collection(s):

All Cerebrovascular disease/Stroke

http://n.neurology.org/cgi/collection/all_cerebrovascular_disease_strok e

Chemotherapy-tumor

http://n.neurology.org/cgi/collection/chemotherapytumor

CT

http://n.neurology.org/cgi/collection/ct

Embolism

http://n.neurology.org/cgi/collection/embolism

Information about reproducing this article in parts (figures,tables) or in its entirety can be found online at:

http://www.neurology.org/about/about_the_journal\#permissions

Information about ordering reprints can be found online:

http://n.neurology.org/subscribers/advertise

Neurology ${ }^{\circledR}$ is the official journal of the American Academy of Neurology. Published continuously since 1951, it is now a weekly with 48 issues per year. Copyright Copyright (? 2011 by AAN Enterprises, Inc.. All rights reserved. Print ISSN: 0028-3878. Online ISSN: 1526-632X.

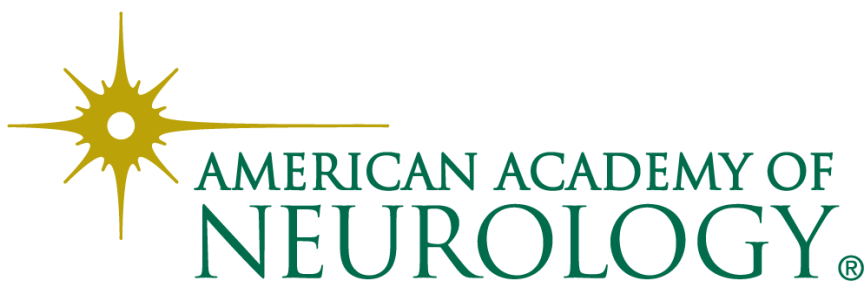

